\title{
Icariin stimulates MC3T3-E1 cell proliferation and differentiation through up-regulation of bone morphogenetic protein-2
}

\author{
HONG CAO $^{1 *}$, YONG KE $^{1 *}$, YING ZHANG $^{2}$, CHANG-JUN ZHANG $^{2}$, WEI QIAN $^{1}$ and GONG-LI ZHANG ${ }^{1}$ \\ ${ }^{1}$ Department of Orthopedic Surgery and ${ }^{2}$ Reproductive Medicine Center, Renmin Hospital, \\ Hubei University of Medicine, Shiyan 442000, Hubei, P.R. China
}

Received September 28, 2011; Accepted November 4, 2011

DOI: $10.3892 /$ ijmm.2011.845

\begin{abstract}
Previous studies suggest that icariin has anabolic effects on bone, but the mechanisms are unknown. We aimed to investigate the osteogenic effects of icariin in an undifferentiated osteoblast cell line by detecting cell morphology, viability, cell cycling and bone morphogenetic protein-2 (BMP-2) expression. We treated pre-osteoblastic MC3T3-E1 cells with different concentrations of icariin [0 (as a control), 10, 20 and $40 \mathrm{ng} / \mathrm{ml}$ ] for 48, 72 and $96 \mathrm{~h}$. Cell morphology, viability and the cell cycle were examined and measured using microscopy, the MTT assay or flow cytometry, respectively. BMP-2-positive cells and BMP-2 protein expression levels in icariin-treated MC3T3-E1 cells were examined using immunohistochemistry staining with fluorescence optical density analysis and Western blotting. MC3T3-E1 cells showed typical characteristics of osteoblasts in response to treatment with icariin. Cells treated with all concentrations of icariin had increased percentages of S-phase cells and decreased percentages of G1-phase cells, especially in the 10 and $20 \mathrm{ng} / \mathrm{ml}$ icariin groups. The number of BMP-2-positive cells and BMP-2 protein expression levels in the 10 and $20 \mathrm{ng} / \mathrm{ml}$ icariin treatment groups were greater compared to the 0 and $40 \mathrm{ng} / \mathrm{ml}$ groups. Treatment of icariin promotes osteoblast MC3T3-E1 proliferation and differentiation in vitro, potentially owing to its role in increasing BMP-2 protein expression. Icariin potentially can be used as a drug in clinical settings to treat osteoporosis.
\end{abstract}

\section{Introduction}

Osteoporosis is a serious public health issue and one of the most important aging-associated diseases, affecting millions

Correspondence to: Dr Ying Zhang, Reproductive Medicine Center, Renmin Hospital, Hubei University of Medicine, Shiyan 442000, P.R. China

E-mail: 33556511@qq.com

*Contributed equally

Key words: osteoporosis, bone morphogenetic protein-2, icariin, MC3T3-E1 cells of people $(1,2)$. It is a silent disease that is defined as 'a skeletal disorder characterized by compromised bone strength, predisposing to an increased risk of fracture' (3). Bone strength reflects the interaction of two main characteristics: bone density and bone quality $(4,5)$. Osteoporosis is characterized by the reduction of bone mass and disorganization of the trabecular architecture, resulting in weakening of the bone.

For postmenopausal women, Epimedium pubescens flavonoids exert a beneficial effect on preventing bone loss (6). Epimedium-derived phytoestrogenic flavonoids can inhibit bone resorption, stimulate bone formation, and prevent ovariectomyinduced osteoporosis, all without resulting in uterine hyperplasia. Peng et al (7) suggested Epimedium-derived flavonoids had an anabolic effect on osteoporotic bone by concomitantly promoting the osteogenic differentiation of bone marrow stromal cells while suppressing adipogenic differentiation.

Icariin, one of the primary active ingredients of Epimedium, reportedly has a potential anabolic effect on the bone (Fig. 1). It can stimulate the proliferation of rat bone marrow stromal cells, increase the number of colony-forming units of fibroblasts that stain positive for alkaline phosphatase and enhance alkaline phosphatase activity, osteocalcin secretion, and calcium deposition levels in a dose-dependent manner (8). Zhao et al (9) showed that icariin exerted its potent osteogenic effect through the induction of Runx 2 expression, production of bone morphogenetic protein-4 (BMP-4), and activation of BMP signaling in vitro. Yin et al (10) and Hsieh et al (11) reported that icariin possibly exerted its osteogenic effects through the induction of BMP-2 gene expression. This effect may contribute to its role in the induction of osteoblast proliferation and differentiation, resulting in bone formation. However, whether the osteogenic effect of icariin also is mediated by BMP-2 and the detailed molecular mechanism of the osteogenic effects of icariin are unclear.

We, therefore, in this study investigated whether icariin could induce morphology and viability changes of MC3T3-E1 cells in vitro; whether icariin decreased or increased MC3T3-E1 cell division by analyzing the cell cycle; and whether the effects of icariin on MC3T3-E1 cells was mediated through BMP-2. Furthermore, we determined differences in the absorbances between the control and experimental groups (cells treated with different doses of icariin) using ANOVA followed by a post hoc analysis of the appropriate type. We then determined differences in the percentages of S-phase cells among 
the treatment and control groups. All statistical analysis were conducted using the SPSS package 10.0 for Windows (SPSS, Inc., Chicago, IL, USA).

\section{Materials and methods}

Cells and reagents. MC3T3-E1 cells were obtained from the Cell Center of the Chinese Academy of Medical Sciences and maintained in $\alpha$-minimum essential medium ( $\alpha$-MEM) (Gibco, Gaithersburg, MD, USA) containing 10\% fetal bovine serum (FBS) and 1\% penicillin/streptomycin (Sigma-Aldrich, St. Louis, MO, USA) in a humidified atmosphere of $5 \% \mathrm{CO}_{2}$ and $95 \%$ air at $37^{\circ} \mathrm{C}$. Icariin was obtained from the Institute of Pharmaceutical Research (Beijing, China) with a purity of $99 \%$. Stock solutions of icariin were prepared in dimethylsulfoxide (DMSO; Sigma, St. Louis, MO, USA) and stored at $-20^{\circ} \mathrm{C}$. The final concentrations of icariin used in the culture were $0,10,20$ and $40 \mathrm{ng} / \mathrm{ml}$. Fetal calf serum (FCS) and trypsin were manufactured by Gibco (Billings, MT, USA), the polyclonal BMP-2 (N14) antibody was produced by Santa Cruz Biotechnology, Inc. (Santa Cruz, CA, USA), and 3,(4,5-dimethylthiazol-2-yl)2,5-diphenyltetrazolium bromide (MTT) was manufactured by Sigma.

Cell proliferation assay. The effect of icariin on cell proliferation was evaluated using the MTT assay. MC3T3-E1 cells were plated in flat-bottomed 96-well plates (Corning, NY, USA) $\left(1 \times 10^{3}\right.$ cells/well) in advance. After incubation for $24 \mathrm{~h}$, the culture medium was replaced with media containing various test agents. During the experiment, the treatments (including medium and icariin) were changed every day, and fresh icariin was added. Four hours before the end of the incubation, the cells were washed twice with $10 \mathrm{mmol} / \mathrm{l}$ phosphate-buffered saline (PBS) (pH 7.2) and incubated with $5 \mathrm{mg} / \mathrm{ml} \mathrm{MTT} \mathrm{(20} \mu \mathrm{l})$ for the last $4 \mathrm{~h}$. The medium then was decanted, formazan salts were dissolved in $150 \mu \mathrm{l}$ DMSO, and the absorbance was determined at $490 \mathrm{~nm}$ using an enzyme-linked immunosorbent assay (ELISA) reader (BioTek Instruments, Winooski, VT, USA).

Cell cycle assay. For the cell cycle assay, MC3T3-E1 cells were plated in 4 tissue culture flasks at a density of $1 \times 10^{5}$ cells $/ \mathrm{ml}$. After $24 \mathrm{~h}$, the culture medium was replaced with a medium containing different concentrations of icariin $(0,10,20$ and $40 \mathrm{ng} / \mathrm{ml}$ ). After $48 \mathrm{~h}$ of incubation, the cells were fixed in $70 \%$ ethanol for $12 \mathrm{~h}$. Next, cells were centrifuged at $260 \mathrm{x} \mathrm{g}$ and washed twice with PBS (200 $\mu \mathrm{l})$. Then, $2 \mu \mathrm{l}$ of RNase A (Invitrogen, Carlsbad, CA, USA) was added, followed by incubation for $30 \mathrm{~min}$ at $37^{\circ} \mathrm{C}$. Propidium iodide (PI, $800 \mu \mathrm{l}$ ) was added, and the mixture was incubated for $30 \mathrm{~min}$ at $4^{\circ} \mathrm{C}$ in the dark. Finally, flow cytometry was performed, and the data were analyzed using CellQuest v3.3 (BD Biosciences, San Jose, CA, USA).

Immunostaining assay. For immunocytostaining assay to detect BMP-2 expression, second-passage cells were trypsinized with $0.25 \%$ trypsin and then resuspended in $\alpha$-MEM containing $10 \%$ fetal bovine serum at $5 \times 10^{3}$ cells $/ \mathrm{ml}$. The cell suspension was transferred into 424 -well plates $(1 \mathrm{ml} /$ well $)$ and incubated at $37^{\circ} \mathrm{C}$ in $5 \% \mathrm{CO}_{2}$ for $24 \mathrm{~h}$. The culture medium

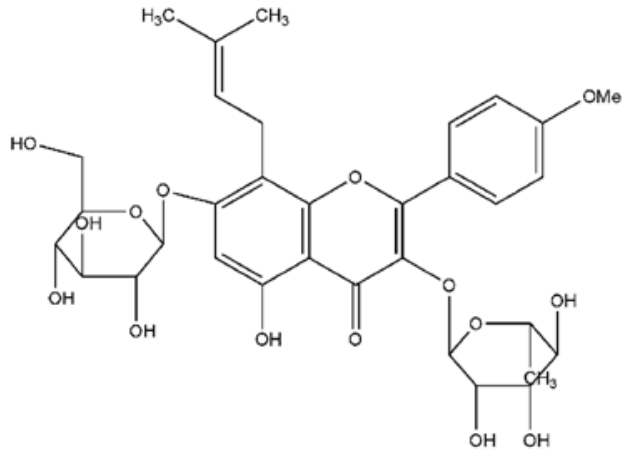

Figure 1. The chemical structural formula of icariin $\left(\mathrm{C}_{33} \mathrm{H}_{40} \mathrm{O}_{15}\right.$, molecular weight 676.65 ) is shown.

was replaced with media containing different icariin concentrations $(0,10,20$ and $40 \mathrm{ng} / \mathrm{ml})$. After $72 \mathrm{~h}$ of icariin stimulation, the cells grew to approximately $80 \%$ confluence. The culture medium then was withdrawn, and the cell monolayer was washed 3 times with PBS and fixed in 4\% paraformaldehyde. Immunocytochemistry was performed using an immunohistochemistry kit (Invitrogen). The cell nuclei were counterstained with 4,6-diamidino-2-phenylindole (DAPI) (Invitrogen). Green cells were identified as BMP-2-positive cells using an immunofluorescence microscope (IX70, Olympus, Japan). One of the 4 wells was chosen randomly from the same batch of cultured cells, and pictures were obtained after the system was adjusted to consistent parameters, such as focus, exposure time, and resolution. The images were processed using ImageJ (National Institutes of Health, Bethesda, MD, USA) for analysis of the fluorescent optical density. The data from the different icariin concentrations were statistically compared.

BMP-2 expression. To detect BMP-2 expression, cell lysates were harvested from the MC3T3-E1 cells and kept on ice for $30 \mathrm{~min}$ after icariin treatment. The lysate was boiled at $100^{\circ} \mathrm{C}$ for $10 \mathrm{~min}$, chilled on ice for $10 \mathrm{~min}$, and then centrifuged at $260 \mathrm{x}$ g for $5 \mathrm{~min}$. The supernatant was quantified using extreme ultraviolet spectroscopy and stored at $-20^{\circ} \mathrm{C}$. The protein extract prepared from the cells was separated using sodium dodecyl sulfate polyacrylamide gel electrophoresis (SDS-PAGE). The proteins on the gel were transferred electrophoretically onto a nitrocellulose membrane at $50 \mathrm{~mA}$ for $1 \mathrm{~h}$ using a semidry blot transfer apparatus (Bio-Rad, Hercules, CA, USA). The nitrocellulose membrane was washed with PBS, incubated with anti-rat BMP-2 polyclonal antibody (1:200 dilution) (Dako, Carpinteria, CA, USA) at room temperature overnight, and further reacted with peroxidase-conjugated anti-rabbit IgG serum (1:100 dilution) (Dako) at room temperature for $2 \mathrm{~h}$. After the reaction and coloration using enhanced chemiluminescence, the relative values for the absorbance of the bands and the absorbance of $\beta$-actin were compared.

\section{Results}

Cell morphology and proliferation. We first examined whether icariin could induce morphology and viability changes of MC3T3-E1 cells in vitro. The effects of different concentrations of icariin on morphologic features of MC3T3-E1 at 48,72 


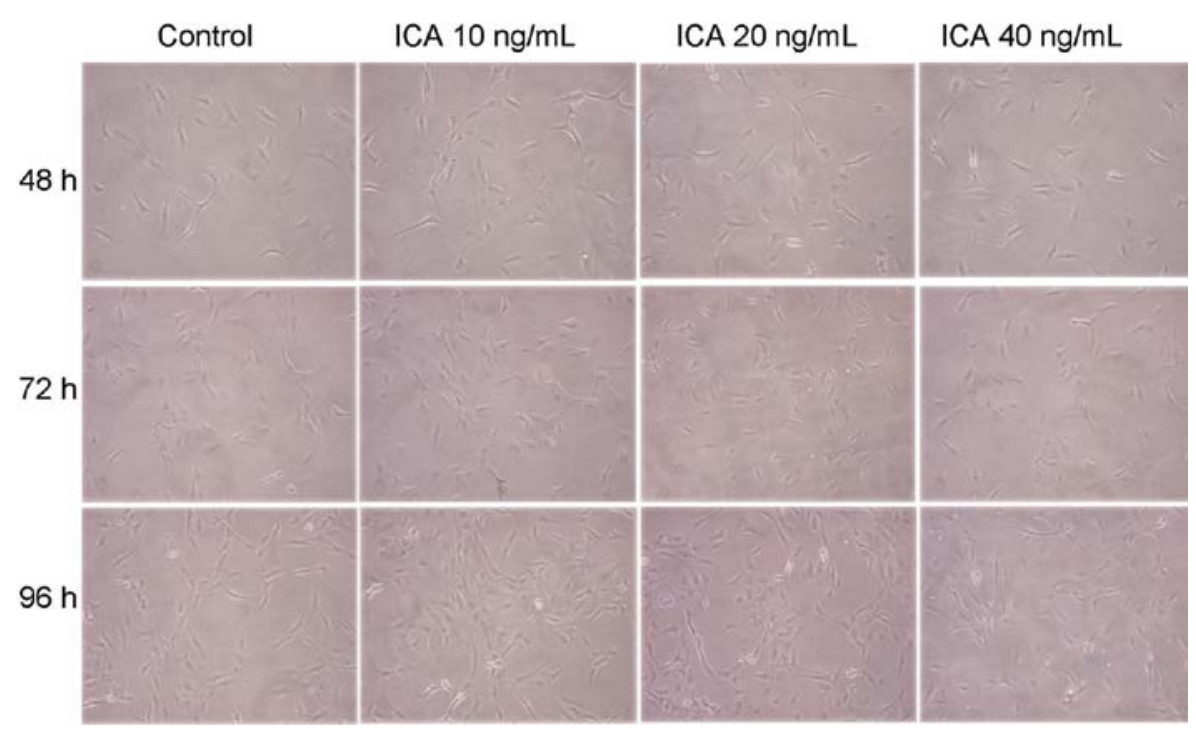

Figure 2. Morphologic features of MC3T3-E1 cells treated with 0, 10, 20 and $40 \mathrm{ng} / \mathrm{ml}$ icariin (ICA) for 48, 72 and $96 \mathrm{~h}$ using an inverted phase contrast microscopy (magnification, $\mathrm{x} 100$ ) are shown.

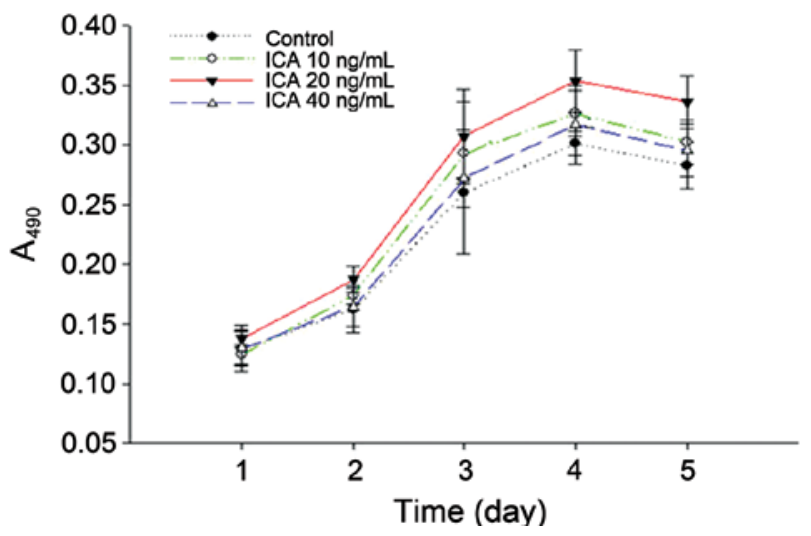

Figure 3. Influence of icariin on MC3T3-E1 cell growth curves. Cells were exposed to 10 or $20 \mathrm{ng} / \mathrm{ml}$ icariin icariin (ICA). The optical density values of the 10 and $20 \mathrm{ng} / \mathrm{ml}$ groups were different in comparison with the 0 and $40 \mathrm{ng} / \mathrm{ml}$ groups. The cell viability in the presence of icariin was higher on Day 4 , and the maximum stimulatory effect on cell proliferation was achieved on Day 4 with $20 \mathrm{ng} / \mathrm{ml}$ icariin. After the fourth day, the optical density curve was decreased; on the fifth day, each group had lower optical density curves to various extents, suggesting that icariin may influence proliferation.

and $96 \mathrm{~h}$ treatment times were examined by using microscopy (Fig. 2). The MC3T3-E1 cells treated with icariin appeared polygonal, spindled, and scale-shaped, typical characteristics of osteoblasts, especially at $96 \mathrm{~h}$ in 10 and $20 \mathrm{ng} / \mathrm{ml}$ groups. In Fig. 3, there were no differences of MC3T3-E1 viability among different groups during the first 2 days. However, on Day 3 and 4, there were a few more cells in the 10 and $20 \mathrm{ng} / \mathrm{ml}$ icariin groups than in the control and $40 \mathrm{ng} / \mathrm{ml}$ icariin groups. Cell proliferation peaked on Day 4 in response to $20 \mathrm{ng} / \mathrm{ml}$ icariin and declined thereafter (Fig. 3). The results indicated that the treatment of icariin could promote MC3T3-E1 cell growth to some extent.

Icariin stimulates cell cycle division. Next, we investigated whether icariin decreased or increased MC3T3-E1 cell division by analyzing the cell cycling. The MC3T3-E1 cells treated with 10, 20 and $40 \mathrm{ng} / \mathrm{ml}$ icariin all showed increased percentages of S-phase cells, especially in the 10 and $20 \mathrm{ng} / \mathrm{ml}$ icariin groups. The representative detection of cell cycling phases was shown in Fig. 4. This suggested that treatment with certain concentrations of icariin stimulated MC3T3-E1 division.

Icariin effects on MC3T3-E1 cells are mediated through $B M P-2$. Then, we examined whether the effects of icariin on MC3T3-E1 cells was mediated through BMP-2. Treatment with 10 or $20 \mathrm{ng} / \mathrm{ml}$ icariin increased the number of BMP-2positive MC3T3-E1 cells compared to the 0 and $40 \mathrm{ng} / \mathrm{ml}$ treatments; accordingly, the fluorescence intensities of BMP-2 staining were enhanced (Fig. 5). BMP-2 protein expression levels in MC3T3-E1 cells treated with icariin were examined using Western blotting (Fig. 6). The target band was present in each group at $31 \mathrm{kD}$. The BMP-2 protein levels in the MC3T3-E1 cells treated with 10 or $20 \mathrm{ng} / \mathrm{ml}$ icariin increased in a dose-dependent manner. However, the BMP-2 protein expression level of the $40 \mathrm{ng} / \mathrm{ml}$ group was slightly increased compared with the control but lower than that of the 10 and $20 \mathrm{ng} / \mathrm{ml}$ groups (Fig. 6). This suggested that $20 \mathrm{ng} / \mathrm{ml}$ icariin was optimal to stimulate MC3T3-E1 cell proliferation.

\section{Discussion}

Icariin is a strong candidate for an osteogenic compound for use in bone tissue engineering (12). A previous study showed that icariin could induce bone marrow stromal cell proliferation (7). In our study, treatment with 10 and $20 \mathrm{ng} / \mathrm{ml}$ of icariin significantly stimulated more MC3T3-E1 cells at the cell cycle S-phase. Increased percentages of S-phase cells and decreased percentages of G1-phase cells suggest active DNA synthesis and cell proliferation. This suggested icariin might have osteogenesis function by stimulating osteoblast proliferation.

Osteoporosis is widely recognized as a major public health problem (13). However, the pathologic features of osteoporosis are complex and involve multiple factors $(14,15)$. Bone mass is regulated by continuous remodeling, which is based 

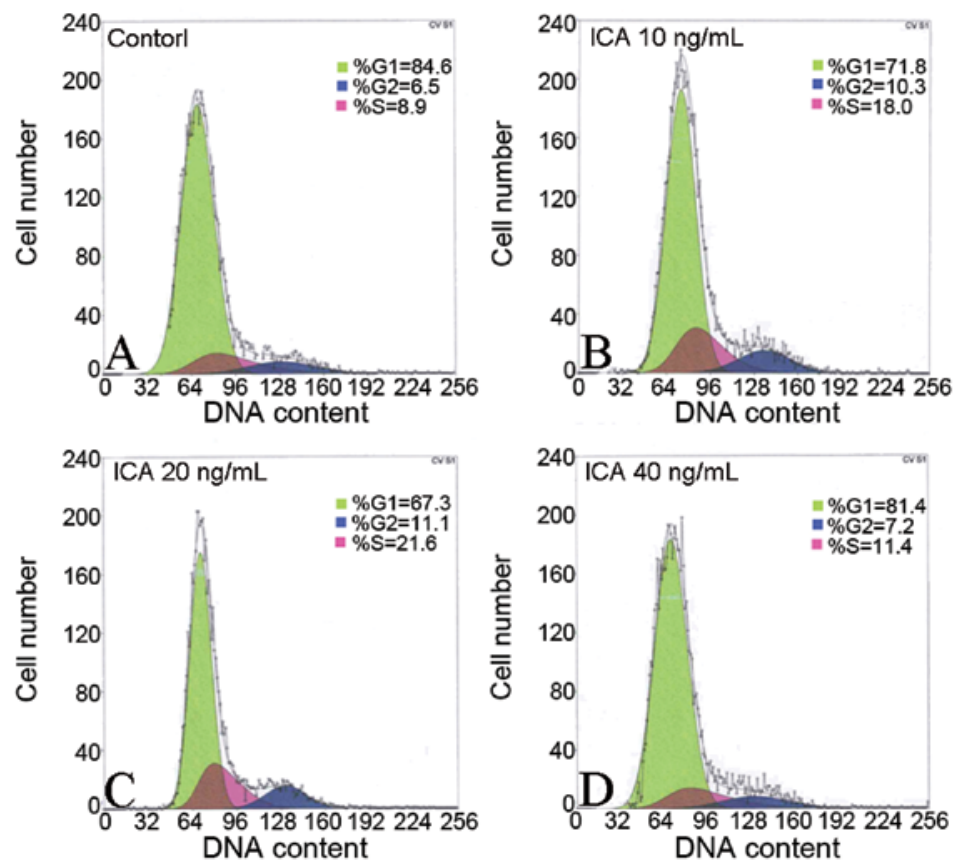

Figure 4. Flow cytometry analysis of MC3T3-E1 cells treated with (A) 0, (B) 10, (C) 20 and (D) $40 \mathrm{ng} / \mathrm{ml}$ concentrations of icariin (ICA) for $48 \mathrm{~h}$. The MC3T3-E1 cells treated with 10,20 or $40 \mathrm{ng} / \mathrm{ml}$ of icariin exhibited increased percentages of S-phase cells and decreased percentages of G1-phase cells, especially in the 10 and $20 \mathrm{ng} / \mathrm{ml}$ groups in comparison to $0 \mathrm{ng} / \mathrm{ml}$ group. The MC3T3-E1 cells treated with $0 \mathrm{ng} / \mathrm{ml}$ icariin were controls.

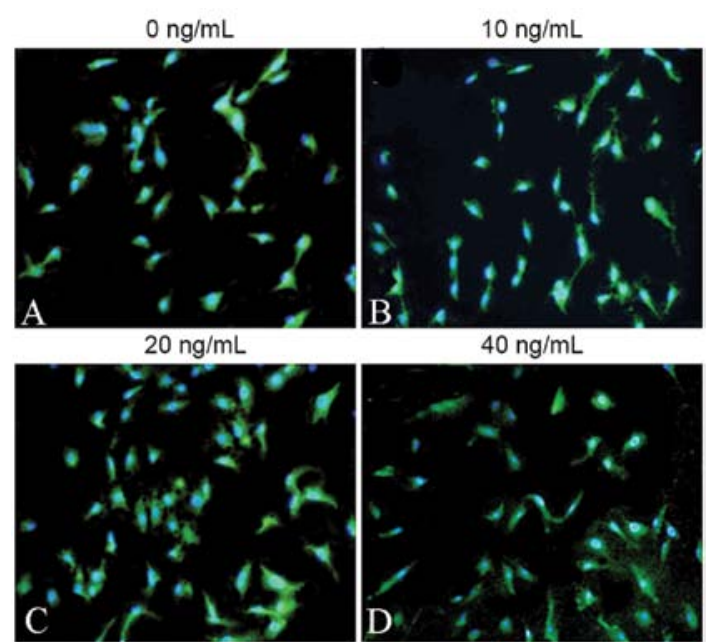

Figure 5. Expression of BMP-2 in MC3T3-E1 cells assessed by immunohistochemistry staining. MC3T3-E1 cells were treated with icariin at (A) 0, (B) 10, (C) 20 and (D) $40 \mathrm{ng} / \mathrm{ml}$ for $72 \mathrm{~h}$ before being fixed for immunostaining. The expression of the BMP-2 protein (FITC, green) and nucle (DAPI, blue) was revealed. The control group and each experimental group displayed positive expression of BMP-2 in the endochylema. BMP-2-positive cell numbers of the 10 and $20 \mathrm{ng} / \mathrm{ml}$ groups were increased in comparison with the 0 and $40 \mathrm{ng} / \mathrm{ml}$ groups, and their fluorescence intensities were enhanced (magnification, x100).

on the balanced action between osteoblastic bone formation and osteoclastic bone resorption (16). This process is well coordinated to maintain bone mass homeostasis and is mediated by multiple signaling pathways, such as parathyroid hormone, transforming growth factor- $\beta$ (TGF- $\beta$ ), and BMP $(17,18)$. BMPs, which belong to the TGF- $\beta$ superfamily, originally were identified as compounds that induce bone and cartilage formation in ectopic extraskeletal sites in vivo. They

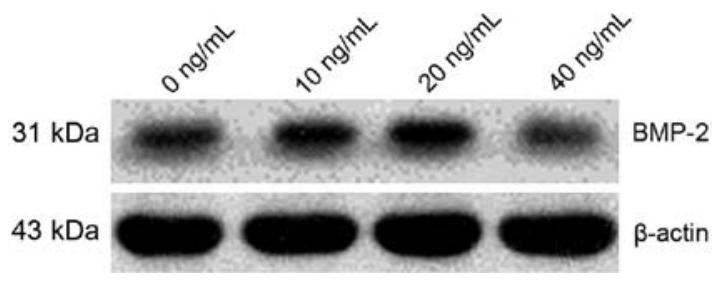

Figure 6. The expression of BMP-2 in MC3T3-E1 cells was examined using Western blotting. The target band at $31 \mathrm{kD}$ was present in each experimental group. The expression levels of the BMP-2 protein in MC3T3-E1 cells treated with 10 and $20 \mathrm{ng} / \mathrm{ml}$ ICA increased with increasing icariin concentrations. The expression of the BMP-2 protein in the $40 \mathrm{ng} / \mathrm{ml}$ group was slightly increased in comparison with the control group but was less than the 10 and $20 \mathrm{ng} / \mathrm{ml}$ groups.

have potent osteogenic effects and control osteoblast proliferation and differentiation during osteogenesis. Several studies of cell-specific inactivation or activation of BMP signals in mice have shown that BMPs regulate postnatal bone remodeling (19-21). The process of bone growth, regeneration, and remodeling is mediated in part by the immediate cell matrix environment (22). Ohba et al (23) suggested two possible mechanisms for the involvement of BMP signaling in the effects of icariin. First, icariin may indirectly activate BMP signaling through extracellular BMPs. Second, icariin may directly activate BMP signaling by interacting with Smads via unknown mechanisms. BMP-2 promotes differentiation mainly through increased intracellular alkaline phosphatase activity, osteocalcin and collagen protein synthesis (24). We studied BMP-2 expression using immunohistochemistry and Western blot analysis. The MC3T3-E1 cell nuclei were labeled using DAPI and were blue under the fluorescence microscope, whereas BMP-2 was labeled with antibodies and was green. The control group and all of the experimental 
groups were positive for BMP-2, and the positive expression was distributed in the cytoplasm. The BMP-2-positive cell numbers of the 10 and $20 \mathrm{ng} / \mathrm{ml}$ groups were increased in comparison with the 0 and $40 \mathrm{ng} / \mathrm{ml}$ groups, and their fluorescence intensities were enhanced. Osteogenic cell proliferation and differentiation play a central role in adequate fracture healing to increase extracellular bone matrix production (25). Certain bone formation agents such as statins have been shown to induce osteoblast differentiation by stimulating the expression of BMP-2 in MC3T3-E1 cells, leading to positive effects on bone formation (26).

In summary, in this in vitro study, we found that icariin treatment could change cell morphology of originally undifferenitated osteoblastic MC3T3-E1 cells, could increase cell viability and proliferation and could promote cell division to some extend. In further analyses, we found that icariin could stimulate differentiation of MC3T3-E1 cells by inducing BMP-2 expression. Our observations suggest that icariin facilitates osteoblast proliferation and differentiation possibly through the BMP-2 signaling pathway.

\section{References}

1. Samelson EJ and Hannan MT: Epidemiology of osteoporosis Curr Rheumatol Rep 8: 76-83, 2006.

2. Lane NE: Epidemiology, etiology, and diagnosis of osteoporosis. Am J Obstet Gynecol 194 (Suppl 2): S3-S11, 2006.

3. Tsurko VV, Leonenko IL, Egorov IV and Krasnoselsky MY: The role of mediator mechanisms in inflammation immunopathogenesis in cardiovascular diseases and osteoporosis. Ter Arkh 81: 92-96, 2009 (In Russian).

4. Bardyn T, Gedet P, Hallermann W and Buchler P: Quantifying the influence of bone density and thickness on resonance frequency analysis: an in vitro study of biomechanical test materials. Int J Oral Maxillofac Implants 24: 1006-1014, 2009.

5. Santiago RC, de Paula FO, Fraga MR, Picorelli Assis NM and Vitral RW: Correlation between miniscrew stability and bone mineral density in orthodontic patients. Am J Orthod Dentofacial Orthop 136: 243-250, 2009.

6. Zhang G, Qin L and Shi Y: Epimedium-derived phytoestrogen flavonoids exert beneficial effect on preventing bone loss in late postmenopausal women: a 24-month randomized, double-blind and placebo-controlled trial. J Bone Miner Res 22: 1072-1079, 2007.

7. Peng S, Zhang G, He Y, et al: Epimedium-derived flavonoids promote osteoblastogenesis and suppress adipogenesis in bone marrow stromal cells while exerting an anabolic effect on osteoporotic bone. Bone 45: 534-544, 2009.

8. Chen KM, Ge BF, Ma HP, Liu XY, Bai MH and Wang Y: Icariin, a flavonoid from the herb Epimedium enhances the osteogenic differentiation of rat primary bone marrow stromal cells. Pharmazie 60: 939-942, 2005.
9. Zhao J, Ohba S, Shinkai M, Chung UI and Nagamune T: Icariin induces osteogenic differentiation in vitro in a BMP- and Runx2dependent manner. Biochem Biophys Res Commun 369: 444-448, 2008.

10. Yin XX, Chen ZQ, Liu ZJ, Ma QJ and Dang GT: Icariine stimulates proliferation and differentiation of human osteoblasts by increasing production of bone morphogenetic protein 2 . Chin Med J (Engl) 120: 204-210, 2007.

11. Hsieh TP, Sheu SY, Sun JS, Chen MH and Liu MH: Icariin isolated from Epimedium pubescens regulates osteoblasts anabolism through BMP-2, SMAD4, and Cbfa1 expression. Phytomedicine 17: 414-423, 2010.

12. Zhao J, Ohba S, Komiyama Y, Shinkai M, Chung UI and Nagamune T: Icariin: a potential osteoinductive compound for bone tissue engineering. Tissue Eng Part A 16: 233-243, 2010.

13. Hiligsmann M, Vanoverberghe M, Neuprez A, Bruyere O and Reginster JY: Cost-effectiveness of strontium ranelate for the prevention and treatment of osteoporosis. Expert Rev Pharmacoecon Outcomes Res 10: 359-366, 2010.

14. Ahn KH, Park HT, Kim T, et al: Relationship between the serum CA-125 level and bone mineral density in healthy pre- and postmenopausal women. Aust NZ J Obstet Gynaecol 50: 371-377, 2010.

15. Allali F,El Mansouri L, Abourazzak F, et al: The effect of past use of oral contraceptive on bone mineral density, bone biochemical markers and muscle strength in healthy pre and post menopausal women. BMC Womens Health 9: 31, 2009.

16. Compston J: Osteoporosis: social and economic impact. Radiol Clin North Am 48: 477-482, 2010.

17. Karsenty G and Wagner EF: Reaching a genetic and molecular understanding of skeletal development. Dev Cell 2: 389-406, 2002.

18. Abe E: Function of BMPs and BMP antagonists in adult bone. Ann NY Acad Sci 1068: 41-53, 2006.

19. Kamiya N, Ye L, Kobayashi T, et al: BMP signaling negatively regulates bone mass through sclerostin by inhibiting the canonical Wnt pathway. Development 135: 3801-3811, 2008.

20. Harada S and Rodan GA: Control of osteoblast function and regulation of bone mass. Nature 423: 349-355, 2003.

21. Yoshida Y, Tanaka S, Umemori $\mathrm{H}$, et al: Negative regulation of BMP/Smad signaling by Tob in osteoblasts. Cell 103: 1085-1097, 2000.

22. Yang X, Tare RS, Partridge KA, et al: Induction of human osteoprogenitor chemotaxis, proliferation, differentiation, and bone formation by osteoblast stimulating factor-1/pleiotrophin: osteoconductive biomimetic scaffolds for tissue engineering. J Bone Miner Res 18: 47-57, 2003.

23. Ohba S, Nakajima K, Komiyama Y, et al: A novel osteogenic helioxanthin-derivative acts in a BMP-dependent manner. Biochem Biophys Res Commun 357: 854-860, 2007.

24. Sumanasinghe RD, Bernacki SH and Loboa EG: Osteogenic differentiation of human mesenchymal stem cells in collagen matrices: effect of uniaxial cyclic tensile strain on bone morphogenetic protein (BMP-2) mRNA expression. Tissue Eng 12: 3459-3465, 2006.

25. Bolander ME: Regulation of fracture repair by growth factors. Proc Soc Exp Biol Med 200: 165-170, 1992.

26. Mundy G, Garrett R, Harris S, et al: Stimulation of bone formation in vitro and in rodents by statins. Science 286: 1946-1949, 1999. 